Review

\title{
An Appraisal of the Field of Metallomics and the Roles of Metal Ions in Biochemistry and Cell Signaling
}

\author{
Wolfgang Maret
}

check for updates

Citation: Maret, W. An Appraisal of the Field of Metallomics and the Roles of Metal Ions in Biochemistry and Cell Signaling. Appl. Sci. 2021, 11, 10846. https://doi.org/10.3390/ app112210846

Academic Editor:

Hanna Lewandowska

Received: 21 October 2021

Accepted: 12 November 2021

Published: 17 November 2021

Publisher's Note: MDPI stays neutral with regard to jurisdictional claims in published maps and institutional affiliations.

Copyright: (C) 2021 by the author. Licensee MDPI, Basel, Switzerland. This article is an open access article distributed under the terms and conditions of the Creative Commons Attribution (CC BY) license (https:/ / creativecommons.org/licenses/by/ $4.0 /)$.
Department of Nutritional Sciences, Faculty of Life Sciences and Medicine, School of Life Course and Population Sciences, King's College London, London SE1 9NH, UK; wolfgang.maret@kcl.ac.uk

\begin{abstract}
Humans require about 20 chemical elements. Half of them are essential metal ions. Many additional, non-essential metal ions are present in our bodies through environmental exposures, including in our diet, with functional consequences. Their accumulation is accelerated due to the increasing pollution of soil, air, water and manufacturing processes that employ chemical elements to which we have not been exposed in our evolutionary history. Yet other metal ions are essential for other forms of life, which calls on life scientists to consider the interactions of life processes with most of the chemical elements in the periodic table. Only in this century have attempts been made to integrate specialty disciplines into a science of bioelements called metallomics. Metallomics forms a fifth group when added to the traditional four building blocks of living cells and their areas of investigations, i.e., sugars (glycomics), fats (lipidomics), proteins (proteomics) and nucleic acids (genomics). Neither an understanding of all the essential metals and their interactions nor the functional impacts of the non-essential metals for life, except established toxic elements such as lead, are widely perceived as important in the basic science communities and in the applied sciences such as medicine and engineering. It is a remarkable oversight that this article attempts to address with representative examples.
\end{abstract}

Keywords: metallomics; metal ion signaling; chemical elements; bioinorganic chemistry; homeostatic control; health outcomes

\section{Introduction}

Biochemistry is at the core of the life sciences and medicine. In the context of a cell, the basic unit of life, biochemistry teaches us the structure, function and metabolism of carbohydrates, lipids, amino acids and nucleobases, the four building blocks of the biological macromolecules. Biochemistry involves the chemical elements sulfur, phosphorus, oxygen, nitrogen, carbon and hydrogen, summarized with the acronym SPONCH elements. It is seen primarily as organic chemistry, the chemistry of the animate world, as opposed to inorganic chemistry, the chemistry of the inanimate world. Generating such an artificial dichotomy of organic vs. inorganic does not do justice to the large number of chemical elements that biological organisms use and gives a wrong impression of life processes that include both organic and inorganic chemistry. Moreover, the SPONCH elements are all non-metals, albeit hydrogen takes a position among the metals in the periodic table and indeed has metallic properties under specific physical conditions [1]. While over $75 \%$ of the elements in the periodic table are metals, they represent only about $2.5 \%$ of the composition of the human body. The crucial roles of metals in biochemistry are often omitted altogether or they are mentioned with only limited reference made to roles such as electron transfer in the mitochondrial respiratory chain, a process so central to aerobic cell biology and dependent on iron and copper centers in proteins. Life is not possible without many metals; indeed it would not even have developed in the first place without the participation of metal ions. Thus, in addition to the six SPONCH elements, at least fourteen other chemical elements are essential for human life, among them are ten metals: sodium, potassium, magnesium, calcium, manganese, iron, cobalt, copper, zinc and molybdenum; 
and four non-metals: chlorine, bromine, iodine and selenium. These elements bring the total count to twenty essential chemical elements in humans [2]. Yet additional elements are essential for non-human forms of life, including metals such as vanadium, tungsten, nickel and lanthanides, and non-metals/metalloids such as boron and silicon [2]. Overall, life makes use of a large number of the chemical elements in the periodic table. Metals are treated in most textbooks together with vitamins that the human body needs but cannot synthesize or has lost the ability to synthesize. Clearly, the body depends on the metal chemical elements in the same way it depends on the non-metal chemical elements. This article draws attention to the consequences of the bias in biochemistry towards the bulk, non-metal elements of life, gives an appraisal of the importance of metals and additional elements as a central, rather than a peripheral, area of biology and emphasizes the need for-and benefits of-further scientific exploration of this significant, yet to be fully charted territory. Further understanding of the biological roles of metal ions has great potential for improving health and preventing disease. While most of the field centers on functions of metal ions as permanent fixtures of metalloproteins, this article highlights areas that increase impact significantly, namely the consequences of perturbing the homeostatic control of metal ions, the role of metal ions as signaling ions in transient interactions with proteins and recent advances in the analytical sciences that allow the description of metal ion distribution and re-distribution with high spatial and temporal resolution as part of the dynamics of cellular functions.

\section{Metallomics}

The field of inorganic biochemistry, a.k.a. bioinorganic chemistry or biological inorganic chemistry, has attempted to address some of the deficiencies resulting from the artificial dichotomy of separating organic and inorganic chemistry with regard to biochemistry. Quite a bit of excitement has been generated about the coordination environments of metal ions in biomolecules, which in many cases revealed an unprecedented and "elegant" chemistry that had millions of years to evolve for specific biological functions, such as enzymatic catalysis. It has stimulated investigations into biomimetic chemistry and synthetic biology by learning from and applying the principles embodied by inorganic biochemistry. However, for the most part, these bioinorganic advances developed almost independently of mainstream biochemistry and never fully bridged the gap to it. In recent years, with the development of analytical omics-based tools for a global profiling of metabolites and macromolecules within biological matrices, the term "metallomics" has been introduced to reflect the technical capacity to measure multiple biometals and metalloproteins within cells and tissues simultaneously and with a remarkable spatial, and sometimes temporal, resolution with methods for metal imaging [3]. Metallomics, in parallel to and in combination with genomics, proteomics and metabolomics, provides new tools and approaches to fully integrate bioinorganic chemistry into the life and applied sciences, bridging the gap that has developed between these disciplines. Without specific mention of metallomics as an emerging discipline, an article focusing on the chemistry of iron exchange among proteins in the biological milieu emphasized the necessity of merging rather than juxtaposing disciplines with the expected outcome of a higher level of understanding of many important questions in the basic and applied biosciences [4].

\section{Quantity vs. Quality of the Chemical Elements, Homeostatic Control and Interactions among the Chemical Elements in Life Processes}

One factor that has led to the present underappreciation of some biometals is confusing quantity with quality and thus treating chemical elements that are essential at lower quantities, referred to as trace elements, as less important than the bulk non-metal elements. Historically, the term "trace elements" is rooted in the early work in the field when analytical methods were inadequate to determine their concentrations precisely [5]. In addition, rather minute quantities are needed on a daily basis. For example, while the human body has about 2-3 g of zinc, the daily requirement is only one thousandth of this amount [6]. Moreover, the cellular concentrations of zinc are in the range of hundreds of micromolar, in 
the order of the concentrations of ATP, which would hardly qualify as a trace [7]. There is a wide spectrum of elemental concentrations within a typical human, from $43 \mathrm{~kg}$ oxygen to $3 \mathrm{mg}$ cobalt, a difference of seven orders of magnitude. Yet, although only two human enzymes require it as part of the vitamin $B_{12}$ prosthetic group, a corrin, and the recommended daily allowance of vitamin $B_{12}$ is only $2.4 \mu \mathrm{g}$, cobalt is as essential as oxygen. Additional proteins are needed for handling the corrin, the classic example being the intrinsic factor, a glycoprotein synthesized in the stomach and responsible for the uptake of vitamin $B_{12}$ in the gut [8]. Its deficiency leads to pernicious anaemia, demonstrating the importance of the minute amounts of cobalt for handling the much larger amounts of iron with three orders of magnitude difference in concentrations; however, there are yet other proteins, e.g., transcobalamins, that are responsible for the transport and delivery of vitamin $B_{12}$. Thus at least three ancillary proteins are necessary, illustrating a critically important fact, namely that not only the element itself (the extrinsic factor) but also its homeostatic control in biological space and time (intrinsic factors) are important. The mechanisms of such homeostatic control of the metal ions represent the interface where significant biochemistry and cell biology meet bioinorganic chemistry of the metals and where a vast potential for applied sciences and modulating health and disease is to be found [9]. The fact that metal metabolism is an integral part of cell function makes it a much more global field compared to, for example, nutritional deficiency or overload alone which are but a small aspect.

In addition to cobalt, copper is essential for iron metabolism as it is needed for oxidising ferrous ions to ferric ions so they can be loaded into transferrin for transport of iron in the blood and other aspects of iron metabolism [10]. Furthermore, the biosynthesis of protoporphyrin IX, the organic molecule of the heme prosthetic group, in the Shemin pathway starts with the enzyme $\delta$-aminolaevulinate dehydratase, which requires zinc as an integral cofactor for catalysis [11]. Zinc deficiency therefore also can lead to anaemia, and so, too, can high doses of zinc, which compete with intestinal iron uptake. Nonessential, toxic metal ions also affect iron metabolism. Lead displaces the catalytic zinc in the dehydratase and inhibits its enzymatic activity, blocking the pathway and resulting in anaemia [12]. Incidentally, zinc is then incorporated into protoporphyrin IX instead of iron, which happens to become fluorescent and can be used as a marker for lead intoxication [13]. In addition to its role in the heme cofactor, iron has to be channelled into non-heme iron proteins and the $\mathrm{Fe}-\mathrm{S}$ proteins, which contain $\mathrm{Fe}-\mathrm{S}$ clusters and need to be synthesized with the use of yet many other ancillary enzymes and proteins $[14,15]$. The heme biosynthetic pathway illustrates the need for synthesizing prosthetic groups for handling metal ions. Another cofactor, a pyranopterin, must be synthesized by cells for handling molybdate [16] Once a prosthetic group/cofactor is assembled, specific enzymes called chelatases or insertases supply the metal ion. The interdependence of metal ions is not unidirectional. Not only do several metal ions influence iron utilization but also iron deficiency, for example, affects intestinal absorption of calcium [17].

\section{Counting the Metal-Protein Interactions with Bioinformatics: Metallproteomes}

In contrast to the few proteins controlling cobalt metabolism, the number of proteins controlling iron or zinc metabolism is at least an order of magnitude greater, including dozens of proteins to fulfil the numerous functions that these metal ions have in catalysis, structure and regulation of proteins [9]. Bioinformatics made it possible to identify metal-binding sites in proteins because such sites are recognized in the primary structure (sequence) by signatures with specific amino acids that provide the donor ligands, with a characteristic number of amino acids between these ligands [18]. This approach provided, for the first time, rather accurate estimates of the total number of proteins whose functions depend on a metal ion, thus highlighting the importance of metalloproteins among proteins [19]. About 50\% of all proteins depend on a metal ion for function [20]. This estimate does not consider the roles of metals in other aspects such as the synthesis of proteins, protein-protein interactions or cellular translocations of proteins. A figure of $3-5 \%$ of all human proteins being dependent on iron has been advanced, even if iron 
in the form of heme is excluded, and at least $10 \%$ depend on zinc, amounting to over 3000 zinc proteins [21,22]. All the additional factors necessary for the synthesis of this high number of metalloproteins also reflect the investment of energy by organisms in obtaining and controlling metal ions. The million-fold increase in concentrations of iron in cells compared to the typical marine environment also attests to the high entropic costs. Bacteria, fungi and plants have biosynthetic pathways for a great variety of low-molecular-weight chelating molecules, called siderophores in the case of iron and amounting to an estimated 500 different compounds [23]. Siderophores assist in overcoming this million-fold gradient by scavenging and acquiring iron from an environment where iron(III) solubility is extremely low, e.g., the solubility product of $\mathrm{Fe}(\mathrm{OH})_{3}$ is $10^{-39}$. The coordination chemistry of siderophores has inspired the synthesis of pharmaceuticals that can be employed to treat disorders of iron metabolism or serve as antibiotics

The proteins controlling metal homeostasis have mutations, many of which give rise to genetic diseases linked to inborn errors of metal metabolism. Though not specifically called intrinsic factors in the case of other metals, these proteins regulating metal ions add enormous significance to metallobiochemistry for medicine (Table 1).

Table 1. Functions of homeostatic proteins of metal metabolism.

\begin{tabular}{|c|c|c|}
\hline Protein & Function & Example $^{a}$ \\
\hline $\begin{array}{l}\text { Membrane metal } \\
\text { ion transport }\end{array}$ & $\begin{array}{l}\text { Export, import-on the plasma } \\
\text { membrane or intracellular } \\
\text { membranes }\end{array}$ & $\begin{array}{c}\text { Zip (SLC39A) family of zinc } \\
\text { tranporters, influx into cytosol (Zn) } \\
\text { ZnT (SLC30A) family of zinc } \\
\text { transporters, efflux from cytosol } \\
(\mathrm{Zn})\end{array}$ \\
\hline Transport & $\begin{array}{l}\text { Cellular, extracellular translocation, } \\
\text { distribution, and redistribution }\end{array}$ & $\begin{array}{c}\text { Tranferrin }(\mathrm{Fe}) \\
\text { Metallothioneins }(\mathrm{Zn}, \mathrm{Cu})\end{array}$ \\
\hline Storage & Long term, short term & $\begin{array}{l}\text { Ferritin (Fe) Metallothioneins ( } \mathrm{Zn} \text {, } \\
\mathrm{Cu})\end{array}$ \\
\hline Metal buffering & $\begin{array}{l}\text { Adjusting steady-state levels of metal } \\
\text { ions and control of transients } \\
\text { employed in cellular signaling with } \\
\text { metal ions. }\end{array}$ & Metallothioneins ( $\mathrm{Zn}, \mathrm{Cu})$ \\
\hline Chaperoning & $\begin{array}{l}\text { Safeguarding metal ions to avoid } \\
\text { adventitious reactions, including } \\
\text { mismetalation of proteins by } \\
\text { transferring the correct metal ion to } \\
\text { the protein that requires it. }\end{array}$ & $\begin{array}{c}\text { Iron chaperone, poly }(\mathrm{rC}) \text { binding } \\
\text { protein (PCBP1) } \\
\text { Copper chaperone (CCS) for } \\
\text { cytosolic superoxide dismutase }\end{array}$ \\
\hline Sensing & $\begin{array}{l}\text { Gauging metal ion concentrations } \\
\text { and triggering transcriptional }(\mathrm{Zn}) \text { or } \\
\text { post-transcriptional }(\mathrm{Fe}) \text { responses for } \\
\text { regulation. }\end{array}$ & $\begin{array}{c}\text { Iron regulatory proteins (IRP-1, -2) } \\
\text { Metal-responsive transcription } \\
\text { factor-1 (MTF-1) }(\mathrm{Zn})\end{array}$ \\
\hline $\begin{array}{l}\text { Metallocofactor } \\
\text { assembly }\end{array}$ & $\begin{array}{c}\text { Insertases, enzymes that insert metal } \\
\text { ions into prosthetic groups or } \\
\text { cofactors. }\end{array}$ & Ferrochelatase $(\mathrm{Fe})$ \\
\hline Metal acquisition & $\begin{array}{l}\text { Metallophores-the majority are } \\
\text { low-molecular-weight compounds, } \\
\text { but some are proteins. }\end{array}$ & $\begin{array}{l}\text { Siderophores }(\mathrm{Fe}) \\
\text { Chalcophores }(\mathrm{Cu}) \\
\text { Zincophores }(\mathrm{Zn})\end{array}$ \\
\hline
\end{tabular}

In the case of copper, for example, Wilson's disease, a treatable copper overload condition, and Menkes disease, a fatal copper deficiency, are both due to mutations of copper transporter proteins (ATP7B and A, respectively). The number of genetic diseases of iron or zinc metabolism is much higher and still increasing. Only one genetic disease resulting from zinc deficiency, a defect in the zinc transporter Zip4 responsible for zinc uptake in the intestine and leading to acrodermatitis enteropathica, had clinical significance 
until recently. However, the recognition that at least twenty-four membrane transporters and at least a dozen metallothioneins are involved in human cellular zinc homeostasis, and that all these proteins have multiple mutations, has resulted in a burgeoning field of genetic disorders of zinc metabolism with high importance for medicine [24]. Mutations do not necessarily affect the transport process itself but can interfere with the regulation of the transporter. A case in point is a particular mutation in ferroportin that results in the change of an amino acid that is involved in SUMOylation and therefore affects trafficking of this cellular iron exporter [25].

\section{Cellular Metal Metabolism as a Part of Metabolic Pathways and Signal Transduction Networks}

The next important aspect is that the metal homeostatic systems do not work in isolation. They are part of the intracellular metabolic pathways and signaling networks and thus are intrinsic to processes that often do not seem to have any connection to a metal ion at first glance. Each metal ion has to be made available or withdrawn specifically in biological time and space depending on the developmental stage, metabolic state and cell fate. Thus any signal that changes the functional state of a cell is potentially linked to signals for re-distribution of metal ions.

Distribution, re-distribution and controlling availability of metal ions for their functions in cytoplasmic or organellar proteins includes specific chemical and biochemical principles. In the case of iron, redox chemistry is critically important and determines whether iron is mobile in the form of the ferrous ion $\left(\mathrm{Fe}^{2+}\right)$ or immobilized in the form of the ferric ion $\left(\mathrm{Fe}^{3+}\right)$. One pathway of iron uptake is receptor-mediated endocytosis of iron [26]. The transferrin receptor binds transferrin with its bound ferric ions. The complex is taken up by cells into endosomes, where the ferric ions are reduced to ferrous ions, which are then released from transferrin and translocated to the cytosol, followed by recycling of the transferrin receptor and transferrin. Ferrous ions can also be released from ferritin, which may receive $\mathrm{Fe}^{2+}$ from a metallochaperone, oxidizes $\mathrm{Fe}^{2+}$ to $\mathrm{Fe}^{3+}$ at a ferroxidase site and stores iron in a core of iron oxide containing up to 4500 ferric ions surrounded by the protein shell $[27,28]$. Zinc, sodium, potassium, magnesium and calcium ions, in contrast to iron or copper ions, are redox inert in biology [29]. Zinc remains in the +2 oxidation state, i.e., $\mathrm{Zn}^{2+}$. The cellular availability of zinc(II) ions is controlled by membrane transporters and by release from vesicular stores or from metallothioneins, which are relatively small cysteine sulfur-rich proteins that contain up to seven bound zinc(II) ions and are highly dynamic in their metal binding and regulation [30]. In the process of zinc dissociation from metallothionein, redox reactions do have a role. In coordination environments with cysteine sulfur ligands, the ligands are redox active and oxidation of the sulfur donor can mobilize zinc(II) ions from sites where they bind with high affinity [31]. The mobilization of metal ions from proteins or subcellular organelles draws attention to the pool of metal ions that are not bound to proteins, referred to as the labile iron pool in the case of iron or the free or mobile zinc pool in the case of zinc. Only indirectly and by inference do we have knowledge about the biological molecules or metabolites binding these metal ions as ligands in these pools as their very nature of exchanging ligands makes the chemical characterization with a speciation analysis very challenging. In E. coli, sulfur-containing amino acids along with mono- and dinucleotides have been identified as candidate ligands [32] Glutathione has been suggested to be a ligand for $\mathrm{Fe}^{2+}$ while multiple ligands have been discussed for $\mathrm{Zn}^{2+}[33,34]$. The terms "free", "labile" and "mobile" are all problematic as they are operational definitions and there is no chemical characterization in vivo. "Free" indicates that the zinc ions are not protein bound, but they are certainly not free in the sense that they do not have any ligands. The terms "labile" and "mobile" are employed to indicate that these metal complexes exchange their ligands. The chemical characteristics differ for each metal ion. An understanding of the differences in coordination chemistry and properties of the metal ions is needed along with how metal ions in complexes with low-molecular-weight ligands are handled with uniquely biological features that ascertain the performance of their functions. A major aspect of metallomics is understanding it as a 
high-throughput metal speciation analysis when combining elemental and molecular mass spectrometry with separation techniques. Metallometabolomics is an emerging field that aims to address these issues [35-37].

\section{Metal Buffering, Muffling and Hormonal Control}

A fundamental fact is that each metal ion must be controlled and buffered in a limited range of concentrations in order to avoid interference with other metal ions, which could lead to mismetalation when putting the wrong metal ion into a functional site of a protein [38]. The underlying principle for this control is the affinity of the metal ion to its ligands, with alkali and alkaline earth metal ions of the s-block in the periodic table having low affinities and metal ions of the d-block having higher affinities that follow the Irving-Williams series [39]. In general, the higher the affinity to the protein the lower the concentration of non-protein bound metal ions. The principle of metal ion buffering is analogous to hydrogen ion/proton $(\mathrm{pH})$ buffering. In the case of metal ion buffering, the metal ion concentration is related to the affinity of the complex for the metal ion and the ratio of metal ion-bound ligand to free ligand. The metal buffering establishes a range of free metal ions covering well over 14 orders of magnitude from millimolar concentrations of alkali metal ions to attomolar concentrations of cuprous $(\mathrm{Cu}(\mathrm{I}))$ ions. Thus, in contrast to $\mathrm{pH}$, where the scale of 14 orders of magnitude ( $\mathrm{pH} 0-14)$ is not realized in biology, a large scale of concentrations of different metal ions indeed is realized in biology and allows the control of biological processes by employing different metal ions. Since buffering is a thermodynamic concept and kinetic factors are also important in controlling biological metal ions, the concept of muffling was introduced [40,41]. Membrane transporters increase or decrease metal ion concentrations and are kinetic factors involved in muffling. They also underlie biological regulation. In addition to transcriptional regulation, membrane metal transporter proteins are endocytosed, recycled and eventually escorted to lysosomes or extracted from membranes for degradation [42].

In addition to the cellular and subcellular control of metal ions and its dynamics there are often systemic and hormonal control at several levels, in the blood, organs and cells. Control of $\mathrm{Ca}^{2+}$ by the peptide hormones, parathyroid hormone and calcitonin, and the ensuing generation of vitamin D metabolites serving as hormones, is well established and so now the peptide hepcidin serves as a hormone in the regulation of iron metabolism. Hepcidin interacts with the iron exporter, ferroportin, to decrease the release of iron from cells $[9,43]$.

Environmental factors (diet, drugs, pollutants) can perturb metal metabolism and result in deficiency, overload or changed distribution of metal ions. This dyshomeostasis has been found to be associated with neurodegeneration and chronic diseases, such as cancer and diabetes, for some metal ions. One functional component in the potential to cause disease is the redox activity of some metal ions and the indirect effects of other, redox-inert metal ions such as calcium and zinc on redox homeostasis and redox stress [29]. Degenerative, metabolic and infectious/communicable diseases are all connected to the dyshomeostasis of metal metabolism, often in a causal rather than an effectual way. Zinc, in particular, is critically important for innate and adaptive immunity and hence adequacy and proper control are major factors for maintaining optimal immunity and regulating inflammation [44]. Zinc, therefore, has become a focus in the susceptibility to viral infections and their progression, as further evident in the present discussions of its role in the COVID19 pandemic and in therapeutic approaches to the disease, though some of the underlying observations had been made many years ago [45,46].

\section{Metal Ion Signaling}

Traditionally, investigations of metals in biochemistry focused on their catalytic, structural or regulatory roles in metalloproteins. The sum of metalloproteins, the metalloproteome, however, is only a part of the metallome [47]. Other biomolecules also have functional groups that interact with metal ions. Thus, in the same vein, one can define met- 
alloglycomes, metallolipidomes and metallogenomes. While the functional implications of metal ions interacting with biomolecules other than proteins are much less acknowledged, there is certainly a great potential for exploring such interactions in the applied sciences. For the interactions of metal ions with monophosphates, it has been pointed out that $\mathrm{Mg}^{2+}$ is favored in order not to capture $\mathrm{Ca}^{2+}$ that needs to be available for signaling purposes [48]. Not only essential but also toxic metal ions bind to the phosphate backbone and the nucleobases in DNA [49]. Such interactions are important for disease mechanisms, therapeutic applications, nanotechnology, biosensing technology and bioelectronics [50]. For metal interactions with lipid vesicles and membranes, the homeostatic control must ascertain that the metals that stabilize these biological structures are available while those that would de-stabilize them are restricted [51]. Similar to nucleic acids, heparin, a glucosaminoglycan, has anionic surfaces that bind cationic metal ions [52]. The binding can be significant for the interactions of glycans with proteins [53].

Metal ions are in transit for incorporation into metalloproteins for their interactions with RNA in ribozymes or riboswitches and other biomolecules. They are taken up by cells and distributed within the cell to the biomolecules in which they function. Any surplus of metal ions may be stored or secreted. There are specific sensor proteins that control the metal homeostatic proteins. Sensing is a form of signaling if proteins detect the metal ion concentrations and have a transduction mechanism to either limit or increase the availability of metal ions. Metal ions have signaling functions with the consequence that not only proteins control metal ions but metal ions also control proteins for a large variety of physiological functions. A role in information transfer necessitates specific mechanisms of signal transduction, which include the dissociation of metal ions from proteins, their release from a cellular compartment (the source and generation of the signal), the specific transfer to another protein where they function (the target of the signal) and ways to revert the system to its initial state, i.e., dissociation of the metal ions from their targets. Such signaling requires another layer in the system of homeostatic control, namely the control of the metal ion transients.

$\mathrm{Ca}^{2+}$ signaling is the prototype of metal ion signaling [54]. More recently, signaling with $\mathrm{Zn}^{2+}$ became established [55]. It involves the release of $\mathrm{Zn}^{2+}$ from intracellular stores such as the endoplasmic reticulum in the cytosol (intracellular signaling) in addition to the release of $\mathrm{Zn}^{2+}$ from cells via, e.g., $\mathrm{Zn}^{2+}$ containing vesicles ("zincosomes") (extracellular $\mathrm{Zn}^{2+}$ signaling) [56]. Another paradigm is the dissociation of zinc from proteins with zinc/thiolate coordination environments elicited by redox signaling, thus in essence transducing redox signals into zinc(II) ion signals [56]. Among the d-block metal ions, copper ions also are thought to have intracellular and extracellular signaling functions-in the brain, including olfaction, circadian rhythm, proliferation, autophagy and fat metabolism $[57,58]$. Phosphodiesterase 3B (PDE3B) involved in cAMP-dependent lipolysis and $\beta$-secretase-1 (BACE), which cleaves amyloid precursor protein (APP) to generate amyloid $\beta(A \beta)$, are targets of copper signaling in the brain and in other tissues [59-63]. Copper storage vesicles (CSV) with estimated copper concentrations of $100 \mathrm{mM}$ have been identified [64]. Due to the prevailing reducing potential in the cell, copper is mainly in the $\mathrm{Cu}(\mathrm{I})$ oxidation state and is handled by metallochaperone proteins that safeguard the cuprous ions and transfer them to the proteins that need them. Free cuprous $(\mathrm{Cu}(\mathrm{I}))$ ions are very toxic due to the Fenton chemistry they catalyze, and accordingly are kept at extremely low, attomolar concentrations. If one converts such low concentrations to the number of copper ions in the small volume of a cell, there is virtually no free copper ion. In this range of concentrations in the small volumes of cells or subcellular compartments stochastic effects need to be considered $[65,66]$. Whether other transition metal ions, such as ferrous ions, have signaling functions is presently unknown.

\section{The Distinction between Essential and Non-Essential Metal Ions}

In the past, analytical instrumentation faced limitations in sensitivity, and scientific reports focused mainly on total metal ion concentrations in biological tissues. Major ad- 
vances in instrumentation and methodologies, such as the use of fluorescent chelating agents, have documented an uneven distribution of metal ions and established fluctuations of metal ion concentrations in cellular space and time [67]. Modern analytical instrumentation, in particular inductively coupled plasma-mass spectrometry (ICP-MS), is sensitive enough to detect the presence of almost all the natural elements in a human body [68]. This achievement highlights yet another significant area, namely the role of "non-essential elements". An essential element is clearly linked to functions. However, the term "non-essential element" is not synonymous with "non-functional element". We are not even certain whether the list of essential metals for humans (or life) is complete as uncertainty lingers about the functions of some metals present at very low abundance. For example, chromium is classified as an essential metal in many countries, although its molecular mode of action remains unknown [69]. Chromium biology illustrates opposing functions of different oxidation states of metal ions. Chromium(III) is considered essential while chromium(VI) in the form of chromate is a carcinogen. Moreover, our knowledge of the functions of metalloids-chemical elements classified by having chemical properties between those of metals and non-metals-is incomplete. Essential roles of some elements have been found only in the last decade, e.g., bromine for humans or lanthanides for some bacteria [70]. Variations in the complement of essential elements used in bacteria compared to humans are also gaining recognition as being important as the human body lives in symbiosis with trillions of cells from microorganisms-in our gut, within our airways and upon our skin. To feed the commensal microbiota properly, elements that are not essential to us are needed by microorganisms. Most recently, 24 bacterial species in our gut microbiome were found to require tungsten, an element that is not essential to humans and normally occurs at extremely low concentrations [71]. These bacteria are involved in detoxifying aldehydes produced in the gut from our diet. Hence, there is a constant chemical and biochemical tug-of-war between the host and its microorganisms in terms of controlling metal availability and ensuring that each obtains its proper share or does not obtain its share as in the case of parasitic microorganisms, which also need essential metal ions for survival. Furthermore, some non-essential elements (strontium, rubidium, nickel) are present at higher amounts than some essential elements in humans. The consequences are largely unknown. Non-essential elements are certainly not passive bystanders; some are mutagens and suspected carcinogens, others compete with essential metals for binding sites. Moreover, if there is no homeostatic control for them-as is often the case, because many have only been introduced to our environment since the industrial revolution and hence have not exerted selection pressure during our evolution: What are their safe upper limits? We know even less about them, largely because we have considered them as nonfunctional. For many of them we do not know the consequence of their natural presence or their presence upon exposure, except for some toxic ones, and even in these cases our knowledge is limited, e.g., the accumulation of cadmium in the human body with age and its effect on ageing healthily [72].

\section{Biometal Ions in the Applied Sciences}

With relevance for applied sciences, we have harnessed the chemical potential of some elements for therapeutic and diagnostic purposes [73]. To name a few, platinum drugs are among the most important anti-cancer drugs, gold compounds are used to treat arthritis in chrysotherapy, lanthanide compounds are contrast agents in magnetic resonance imaging (MRI) and radioactive isotopes of metal ions such as synthetic technetium, gallium and many other elements are used in SPECT (single-photon emission computed tomography) and PET (positron emission tomography) imaging. In the chemical and biological sciences, specific radioisotopes or stable isotopes are employed as tracers to investigate the kinetics of metal metabolism or as spectroscopic probes to characterize the coordination environments of metals in biomolecules. Various new technologies, especially in the electronics industry, utilize a large number of metals to which we have never been exposed in our evolutionary history [74]. We are now exposed to these metals through soil, water and air, including 
accumulation in food webs, or even through implantation of prosthetic devices. There are huge gaps in understanding the ensuing effects on health.

In current biomedical research, trace metal levels are rarely controlled or tested as such control requires special skills and analytical instrumentation that is not always available, although, compared to complex organic molecules, most chemical elements are relatively easy and cheap to measure and to monitor [75]. The presence of trace metals is a variable in biological experiments and can potentially influence a myriad of outcomes in research. High purity analytical grade chemical reagents often have certified upper limits on trace levels of metals, but they are usually in the parts per million (ppm) range-orders of magnitude above the concentrations at which some metal ions affect biological systems. Quality control of biochemical or molecular biology reagents raises additional concerns in this regard because "molecular biology grade" is an operational definition for a specialty grade that is suitable in applications where control of enzymatic, e.g. nucleases, and bacterial impurities is necessary. Therefore, additional awareness is needed in how to control metal ion concentrations in experimental designs and how to choose chemicals and biochemicals for specific applications.

Meaningful tests that relate optimal concentrations to health outcomes do not exist for the majority of the non-essential chemical elements. As the levels of pollution with highly reactive metals in our environment increases and associated negative health outcomes are observed, developing such tests is a pressing issue with great economic impact for lowering the burden of disease and living healthily, the bioeconomy, the sustainability of the biosphere and human civilization. Prominent recent examples of pollution and the consequences for health being realized more widely are the contamination of rice with arsenic and the presence of lead in the atmosphere of large cities [76,77].

Tremendous opportunities exist to advance the field of metallomics in a range of disciplines, from biomineralization in a field that has been named biomateriomics, to environmental pollution and toxicology [78], to fundamental mechanistic biochemistry to understand disease aetiology and progression [79], to applications in imaging science, through to the use of radionuclides of essential metals including copper $\left({ }^{64} \mathrm{Cu},{ }^{62} \mathrm{Cu}\right)$, zinc $\left({ }^{62} \mathrm{Zn},{ }^{63} \mathrm{Zn}\right)$, manganese $\left({ }^{52} \mathrm{Mn}\right)$ and surrogates of iron (gallium as ${ }^{68} \mathrm{Ga}$ and ${ }^{67} \mathrm{Ga}$ ) and potassium (rubidium as ${ }^{82} \mathrm{Rb}$, thallium as ${ }^{201} \mathrm{Tl}$ ) as PET and SPECT imaging agents in living animals and humans and as radiotracers in cells and tissues. "PET metallomics" is the name given to this developing new field of investigating metal metabolism in health and disease by exploring the new and growing availability of radionuclides [80]. The advent of high resolution elemental imaging with laser ablation coupled with ICP-MS at the microscopic scale and its integration with multidimensional imaging from the nanoscale to the macroscale, including molecular mass spectrometry and other imaging modalities, offers an unparalleled opportunity to enhance our understanding of the elements of life and death within the biological context [81-83].

\section{A Call for Multidisciplinary and Interdisciplinary Research: Metametallomics}

The potential of the field of metallomics will be recognized in other disciplines and the applied sciences only with increased awareness of the basic issues discussed here. Education, funding bodies, scientific societies and further health and environmental research could assist in this recognition as metal ions have effects over a wide range of concentrations relevant for nutrition, pharmacology and toxicology. A wider understanding of the role of the chemical elements in biology will make a huge impact on human health. Further insights will advance bioengineering in applications such as bioremediation to decrease metal ion concentrations in soils and water, biofortification of certain crops to increase their dietary value for micronutrients or employing the catalytic power and enantioselectivity of metalloenzymes for synthetic chemistry. A long-term change in education-how biochemistry is being taught-is needed. It requires further integration of biometals and other chemical elements of life into university curricula in different fields. Metallomics may serve as a platform for integration. Indeed, among the emer- 
gence of many omics disciplines, it was recognized that metallomics encapsulates a new focus, refers to a comprehensive collection and is easy to say and to understand [84]. Connecting metallomics to other "omics", bioinformatics and the role of metal ions to environmental sciences, such as biomarkers for exotoxicology/ecotoxicology, bioleaching and phytoremediation, generates promising synergism [37]. When including environmental and genetic factors to account for variability of the metallome, the field is referred to metametallomics [70]. However, the "omics" disciplines are mainly comprised of technologies and methods rather than fundamental principles. Additional approaches to teaching such principles are therefore needed. Scientific societies, conferences and journals often are too narrowly focused and need to adapt to multidisciplinary and interdisciplinary facets of the roles of the chemical elements in biology. Funding bodies could facilitate the transition to a wider recognition of the scope and impact of the field in the basic and applied sciences. In the United Kingdom, the Biotechnology and Biological Sciences Research Council's NIBB (Networks in Industrial Biotechnology and Bioenergy) initiative with a program on "The elements of bioremediation, biomanufacturing and bioenergy. Metals in Biology" promotes collaboration between academia and industry and is a step in the right direction (https: / / mib-nibb.webspace.durham.ac.uk; accessed on 11 November 2021). Research funding bodies should consider similar initiatives and stimuli for clinical, chemical and environmental research. As a metallomics community we need to actively collaborate and consolidate our expertise, both to improve the scientific literacy within the biomedical community about the essential role of inorganic elements and also to provide the tools and expertise to encourage wider engagement with this area. This is the approach that has been adopted within the London Metallomics Facility (LMF, https:/ / www.kcl.ac.uk/research/metallomics; accessed on 11 November 2021), funded by the Wellcome Trust and King's College London [85], by providing a core facility for a wider research community as an exemplar for advancing the science of the bioelements. We believe it is essential not only to bring together a critical mass of active researchers in this area, but also to strongly advocate for the field, so that it is not just perceived as another untargeted omics-based platform, but an essential link between the organic and inorganic world.

Funding: The research linked to this review was funded by the Wellcome Trust, Multi-User Equipment Grant “The London Metallomics Facility” (202902/Z/16/Z).

Institutional Review Board Statement: Not applicable.

Informed Consent Statement: Not applicable.

Acknowledgments: I thank my colleagues at King's College London, Robert Hider and Phil Blower, Surjit K. S. Srai (University College London) and Ian Mudway (Imperial College London), who are all part of the London Metallomics Consortium (LMC), for discussions that led to this manuscript. The LMC comprises "a critical mass" of academic investigators from several London Universities (King's College (KCL), University College (UCL), Queen Mary University (QMU), Imperial College (IC)) with various backgrounds and a common interest in metallomics. It also includes Sophie Moore (KCL), David Green (IC), Maciej Garbowski (UCL), Guy Rutter (IC). John Viles and Claudio Raimondi (QMU).

Conflicts of Interest: The author declares no conflict of interest.

\section{References}

1. Desgreniers, S. A milestone in the hunt for metallic hydrogen. Nature 2020, 577, 626-627. [CrossRef] [PubMed]

2. Maret, W. The metals in the biological periodic system of the elements: Concepts and conjectures. Int. J. Mol. Sci. 2016, $17,66$. [CrossRef] [PubMed]

3. Haraguchi, H. Metallomics as integrated biometal science. J. Anal. At. Spectrom. 2004, 19, 5-14. [CrossRef]

4. Moulis, J.-M. Cellular dynamics of transition metal exchange on proteins: A challenge but a bonanza for coordination chemistry. Biomolecules 2020, 10, 1584. [CrossRef]

5. Underwood, E. Trace Elements in Human and Animal Nutrition, 4th ed.; Academic Press: New York, NY, USA, 1977.

6. Maret, W. Zinc biochemistry: From a single zinc enzyme to a key element of life. Adv. Nutr. 2013, 4, 82-91. [CrossRef] [PubMed] 
7. Maret, W. Zinc and human disease. In Interrelations between Essential Metal Ions and Human Disease; Sigel, A., Sigel, H., Sigel, R.K.O., Eds.; Metal Ions in Life Sciences; Springer Science+Business Media: Dordrecht, The Netherlands, 2013; Volume 13, pp. 389-414.

8. Stabler, S.P. Vitamin B12 deficiency. N. Engl. J. Med. 2013, 368, 149-160. [CrossRef]

9. Maret, W.; Wedd, A. (Eds.) Binding, Transport and Storage of Metal Ions in Biological Cells; Royal Society of Chemistry: Cambridge, $\mathrm{UK}, 2014$.

10. Gulec, S.; Collins, J.F. Molecular mediators governing iron-copper interactions. Annu. Rev. Nutr. 2014, 34, 95-116. [CrossRef]

11. Role of zinc in $\delta$-aminolevulinate dehydratase. Nutr. Rev. 1980, 38, 255-256.

12. Simons, T.J.B. The affinity of human erythrocyte porphobilinogen synthase for $\mathrm{Zn}^{2+}$ and $\mathrm{Pb}^{2+}$. Eur. J. Biochem. 1995, 234, 178-183. [CrossRef]

13. Maret, W. The bioinorganic chemistry of lead in the context of its toxicity. In Lead: Its Effects on Environment and Health; Sigel, A., Sigel, H., Sigel, R.K.O., Eds.; Metal Ions in Life Sciences; W. de Gruyter: Berlin, Germany, 2017; Volume 17, pp. 1-20.

14. Wachnowsky, C.; Fidai, I.; Cowan, J.A. Iron-sulfur cluster biosynthesis and trafficking-Impact on human disease conditions. Metallomics 2018, 10, 9-29. [CrossRef]

15. Braymer, J.J.; Freibert, S.A.; Rakwalska-Bange, M.; Lill, R. Mechanistic concepts of iron-sulfur biogenesis in biology. Biochim. Biophys. Acta 2021, 1868, 118863. [CrossRef] [PubMed]

16. Kirk, M.L.; Kc, K. Molybdenum and tungsten cofactors and the reactions they catalyze. In Transition Metals and Sulfur-A Strong Relationship for Life; Sosa Torres, M., Kroneck, P., Eds.; W. De Gruyter: Berlin, Germany, 2020; pp. 313-342.

17. Asowata, E.O.; Olusanya, O.; Abaakil, K.; Chichger, H.; Srai, S.K.S.; Unwin, R.J.; Marks, J. Diet-induced iron deficiency in rats impacts small intestinal calcium and phosphate absorption. Acta Physiol. 2021, 232, e13650. [CrossRef]

18. Vallee, B.L.; Auld, D.S. Zinc coordination, function, and structure of zinc enzymes and other proteins. Biochemistry 1990, 29 , 5647-5659. [CrossRef]

19. Andreini, C.; Bertini, I.; Cavallaro, G.; Holliday, G.L.; Thornton, J.M. Metal ions in biological catalysis: From enzymes databases to general principles. J. Biol. Inorg. Chem. 2008, 13, 1205-1218. [CrossRef]

20. Thomson, A.J.; Gray, H.B. Bioinorganic chemistry. Curr. Opin. Chem. Biol. 1998, 2, 155-158. [CrossRef]

21. Andreini, C.; Banci, L.; Bertini, I.; Rosato, A. Counting the zinc-proteins encoded in the human genome. J. Proteome Res. 2006, 5, 196-201. [CrossRef]

22. Andreini, C.; Putignano, V.; Rosato, A.; Banci, L. The human iron-proteome. Metallomics 2018, 10, 1223-1231. [CrossRef] [PubMed]

23. Hider, R.C.; Kong, X. Chemistry and biology of siderophores. Nat. Prod. Rep. 2010, 27, 625-796. [CrossRef]

24. Hogstrand, C.; Maret, W. Genetics of Human Zinc Deficiencies, ELS (Encyclopedia of Life Sciences); John Wiley \& Sons, Ltd.: Chichester, UK, 2016. [CrossRef]

25. Bayele, H.K.; Srai, S.K.S. A disease-causing mutation K240E disrupts ferroportin trafficking by SUMO (ferroportin SUMOylation). Biochem. Biophys. Rep. 2021, 25, 100873. [CrossRef] [PubMed]

26. Hentze, M.W.; Muckenthaler, M.U.; Andrews, N.C. Balancing acts: Molecular control of mammalian iron metabolism. Cell 2004, 117, 285-297. [CrossRef]

27. Patel, S.J.; Protchenko, O.; Shakoury-Elizeh, M.; Baratz, E.; Jadhav, S.; Philpott, C.C. The iron chaperone and nucleic acidbinding activities of poly(RC)-binding protein 1 are separable and independently essential. Proc. Natl. Acad. Sci. USA 2021, 118, e2104666118. [CrossRef] [PubMed]

28. Bradley, J.M.; Moore, G.R.; Le Brun, N.E. Mechanisms of iron mineralization in ferritins: One size does not fit all. J. Biol. Inorg. Chem. 2014, 19, 775-785. [CrossRef]

29. Maret, W. The redox biology of redox-inert zinc ions. Free Radic. Biol. Med. 2019, 134, 311-326. [CrossRef]

30. Krężel, A.; Maret, W. The bioinorganic chemistry of mammalian metallothioneins. Chem. Rev. 2021. [CrossRef]

31. Maret, W. Zinc and sulfur: A critical biological partnership. Biochemistry 2004, 43, 3301-3309. [CrossRef]

32. Brawley, H.N.; Lindahl, P.A. Low-molecular-mass labile metal pools in Escherichia coli: Advances using chromatography and mass spectrometry. J. Biol. Inorg. Chem. 2021, 26, 479-494. [CrossRef] [PubMed]

33. Hider, R.C.; Kong, X.L. Glutathione: A key component of the cytoplasmic labile iron pool. Biometals 2011, $24,1179-1187$. [CrossRef]

34. Krężel, A.; Maret, W. The biological inorganic chemistry of zinc ions. Arch. Biochem. Biophys. 2016, 611, 3-19. [CrossRef]

35. Mounicou, S.; Lobinski, R. Challenges to metallomics and analytical chemistry solutions. Pure Appl. Chem. 2008, 80, 2565-2575. [CrossRef]

36. García-Sevillano, M.A.; García-Barrera, T.; Gómez-Ariza, J.L. Application of metallomic and metabolomic approaches in exposure experiments on laboratory mice for environment metal toxicity assessment. Metallomics 2014, 6, 237-248. [CrossRef]

37. Singh, V.; Verma, K. Metals from cell to environment: Connecting metallomics with other omics. Open J. Plant Sci. 2018, 3 , 001-014.

38. Robinson, N.J.; Glasfeld, A. Metalation: Nature's challenge in bioinorganic chemistry. J. Biol. Inorg. Chem. 2020, 25, 543-545. [CrossRef]

39. Irving, H.; Williams, R.J.P. Order of stability of metal complexes. Nature 1948, 162, 746-747. [CrossRef]

40. Thomas, R.C.; Coles, J.A.; Deitmer, J.W. Homeostatic muffling. Nature 1991, 350, 564. [CrossRef] 
41. Colvin, R.A.; Holmes, W.R.; Fontaine, C.P.; Maret, W. Cytosolic zinc buffering and muffling: Their role in intracellular zinc homeostasis. Metallomics 2010, 2, 306-317. [CrossRef] [PubMed]

42. Bowers, K.; Srai, S.K.S. The trafficking of metal ion transporters of the Zrt- and Irt-like protein family. Traffic 2018, 19, 813-822. [CrossRef]

43. Nemeth, E.; Tuttle, M.S.; Powelson, J.; Vaughn, M.B.; Donovan, A.; Ward, D.M.; Ganz, T.; Kaplan, J. Hepcidin regulates cellular iron efflux by binding to ferroportin and inducing its internalization. Science 2004, 306, 2090-2093. [CrossRef]

44. Wessels, I.; Fischer, H.J.; Rink, L. Dietary and physiological effects of zinc on the immune system. Annu. Rev. Nutr. 2021, 41, 133-175. [CrossRef]

45. Wessels, I.; Rolles, B.; Rink, L. The potential impact of zinc supplementation on COVID-19 pathogenesis. Front. Immunol. 2020, 11, 1712. [CrossRef]

46. Doboszewska, U.; Wlaź, P.; Nowak, G.; Młyniec, K. Targeting zinc metalloenzymes in coronavirus disease 2019. Br. J. Pharmacol. 2020, 177, 4887-4898. [CrossRef]

47. Maret, W. Metalloproteomics, metalloproteomes, and the annotation of metalloproteins. Metallomics 2010, 2, 117-125. [CrossRef]

48. Grauffel, C.; Dudev, T.; Lim, C. Metal affinity/selectivity of monophosphate-containing signaling/lipid molecules. J. Chem. Theory Comput. 2021, 17, 2444-2456. [CrossRef] [PubMed]

49. Kanellis, V.G.; Dos Remedios, C.G. A review of heavy metal cation binding to deoxyribonucleic acids for the creation of chemical sensors. Biophys. Rev. 2018, 10, 1401-1414. [CrossRef]

50. Shamsi, M.H.; Kraatz, H.-B. Interactions of metal ions with DNA and some applications. J. Inorg. Organomet. Polym. Mat. 2013, 23, 4-23. [CrossRef]

51. Hong, J.; Yang, H.; Pang, D.; Wei, L.; Deng, C. Effects of mono- and di-valent metal cations on the morphology of lipid vesicles. Chem. Phys. Lipids 2018, 217, 19-28. [CrossRef]

52. Katner, S.J.; Johnson, W.E.; Peterson, E.J.; Page, P.; Farrell, N.P. Comparison of metal-ammine compounds binding to DNA and heparin. Glycans as ligands in bioinorganic chemistry. Inorg. Chem. 2018, 57, 3116-3125.

53. Zhang, F.; Liang, X.; Beaudet, J.M.; Lee, Y.; Linhardt, R.J. The effects of metal ions on heparin/heparin sulfate-protein interactions. J. Biomed. Technol. Res. 2014, 1. [CrossRef]

54. Carafoli, E.; Krebs, J. Why calcium? How calcium became the best communicator. J. Biol. Chem. 2016, 291, 20849-20857. [CrossRef]

55. Fukuda, T.; Kambe, T. Zinc Signals in Cellular Functions and Disorders; Springer: Tokyo, Japan, 2014.

56. Maret, W. Regulation of cellular zinc ions and their signaling functions. In Zinc Signaling, 2nd ed.; Fukuda, T., Kambe, T., Eds.; Springer Nature: Singapore, 2019; pp. 5-22.

57. Chang, C.J. Searching for harmony in transition-metal signaling. Nat. Chem. Biol. 2015, 11, 744-747. [CrossRef] [PubMed]

58. Chung, C.Y.-S.; Posimo, J.M.; Lee, S.; Tsang, T.; Davis, J.M.; Brady, D.C.; Chang, C.J. Activity-based ratiometric FRET probe reveals oncogene-driven changes in labile copper pools induced by altered glutathione metabolism. Proc. Natl. Acad. Sci. USA 2019, 116, 18285-18294. [CrossRef]

59. Angeletti, B.; Waldron, K.J.; Freeman, K.B.; Bawagan, H.; Hussain, I.; Miller, C.C.; Lau, K.F.; Tennant, M.E.; Dennison, C.; Robinson, N.J.; et al. BACE1 cytoplasmic domain interacts with the copper chaperone for superoxide dismutase-1 and binds copper. J. Biol. Chem. 2005, 280, 17930-17937. [CrossRef]

60. Krishnamoorthy, L.; Cotruvo, J.A., Jr.; Chan, J.; Kaluarachchi, H.; Muchenditsi, A.; Pendyala, V.S.; Jia, S.; Aron, A.T.; Ackerman, C.M.; Vander Wal, M.N.; et al. Copper regulates cyclic AMP-dependent lipolysis. Nat. Chem. Biol. 2016, 12, 586-592. [CrossRef] [PubMed]

61. Grubman, A.; White, A.R. Copper as a key regulator of cell signalling pathways. Expert Rev. Mol. Med. 2014, 16, e11. [CrossRef] [PubMed]

62. Kardos, J.; László, H.; Simon, A.; Jablonkai, I.; Kovács, R.; Jemnitz, I. Copper signalling: Causes and consequences. Cell Commun. Signal. 2018, 16, 71. [CrossRef]

63. Ackerman, C.M.; Chang, C.J. Copper signaling in the brain and beyond. J. Biol. Chem. 2018, 293, 4628-4635. [CrossRef]

64. Leary, S.C.; Ralle, M. Advances in visualization of copper in mammalian systems using X-ray fluorescence microscopy. Curr. Opin. Chem. Biol. 2020, 55, 19-25. [CrossRef]

65. Bal, W.; Kurowska, E.; Maret, W. The final frontier of $\mathrm{pH}$ and the undiscovered country beyond. PLoS ONE 2012, 7, e45832. [CrossRef] [PubMed]

66. Goch, W.; Bal, W. Stochastic or not? Method to predict and quantify the stochastic effects on the association equilibria in nanoscopic systems. J. Phys. Chem. A 2020, 124, 1421-1428. [CrossRef]

67. Carter, K.P.; Young, A.M.; Palmer, A.E. Fluorescent sensors for measuring metal ions in living systems. Chem. Rev. 2014, 114, 4564-4601. [CrossRef]

68. Haraguchi, H.; Ishii, A.; Hasegawa, T.; Matsuura, H.; Umemura, T. Metallomics on all-elements analysis of salmon egg cells and fractionation analysis of metals in cell cytoplasm. Pure Appl. Chem. 2008, 80, 2595-2608. [CrossRef]

69. Maret, W. Chromium in Human Health, Metabolic Syndrome, and Diabetes. In Essential Metals in Medicine: Therapeutic Use and Toxicity of Metal Ions in the Clinic; Carver, P.L., Guest, E., Sigel, A., Freisinger, E., Sigel, R.K.O., Eds.; Metal Ions in Life Sciences; W. de Gruyter: Berlin, Germany, 2019; Volume 19, pp. 231-251.

70. Maret, W. Metallomics: The science of biometals and biometalloids. In Metallomics; Arruda, M.A.Z., Ed.; Springer International Publishing: AG, USA, 2018; Adv. Exp. Med. Biol.; Volume 1055, pp. 1-20. 
71. Schut, G.J.; Thorgersen, M.P.; Poole II, F.L.; Haja, D.K.; Putumbaka, S.; Adams, M.W.W. Tungsten enzymes play a role in detoxifying food and antimicrobial aldehydes in the human gut microbiome. Proc. Natl. Acad. Sci. USA 2021, 118, e2109008118. [CrossRef]

72. Maret, W.; Moulis, J.-M. The bioinorganic chemistry of cadmium in the context of its toxicity. In Cadmium: From Toxicity to Essentiality; Sigel, A., Sigel, H., Sigel, R.K.O., Eds.; Metal Ions in Life Sciences; Springer Science+Business Media: Dordrecht, The Netherlands, 2013; Volume 11, pp. 11-29.

73. Chellan, P.; Sadler, P.J. The elements of life and medicines. Phil. Trans. R. Soc. 2015, 373, 20140182. [CrossRef]

74. King, A.H. Our elemental footprint. Nat. Mater. 2019, 18, 408-409. [CrossRef] [PubMed]

75. Zief, M.; Mitchell, J.M. Contamination Control in Trace Metal Analysis; Wiley: New York, NY, USA, 1976.

76. Resongles, E.; Dietze, V.; Green, D.C.; Harrison, R.M.; Ochoa-Gonzalez, R.; Tremper, A.H.; Weiss, D.J. Strong evidence for the continued contribution of lead deposited during the 20th century to the atmospheric environment in London of today. Proc. Natl. Acad. Sci. USA 2021, 118, e2102791118. [CrossRef]

77. Beans, C. Keeping arsenic out of rice. Proc. Natl. Acad. Sci. USA 2021, 118, e2113071118. [CrossRef]

78. Selley, L.; Schuster, L.; Marbach, H.; Forsthuber, T.; Forbes, B.; Gant, T.W.; Sandström, T.; Camiña, N.; Athersuch, T.J.; Mudway, I.; et al. Brake dust exposure exacerbates inflammation and transiently compromises phagocytosis in macrophages. Metallomics 2020, 12, 371-386. [CrossRef]

79. Unosson, J.; Kabéle, M.; Boman, C.; Nyström, R.; Sadiktsis, I.; Westerholm, R.; Mudway, I.S.; Purdie, E.; Raftis, J.; Miller, M.R.; et al. Acute cardiovascular effects of controlled exposure to dilute Petrodiesel and biodiesel exhaust in healthy volunteers: A crossover study. Part. Fibre Toxicol. 2021, 18, 22. [CrossRef] [PubMed]

80. Blower, P.J. Insights into trace metal metabolism in health and disease from PET: "PET metallomics". J. Nucl. Med. 2018, 59, 1355-1359.

81. Doble, P.A.; Gonzales de Vega, R.; Bishop, D.P.; Hare, D.J.; Clases, D. Laser ablation-inductively coupled plasma-mass spectrometry imaging in biology. Chem. Rev. 2021, 121, 11769-11822. [CrossRef]

82. Kutscher, D.; Asogan, D.; Mudway, I.; Brekke, P.; Beales, C.; Wang, X.; Perkins, M.W.; Maret, W.; Stewart, T.J. Imaging of trace elements using laser ablation-inductively coupled plasma-mass spectrometry: Emerging new applications. Spectroscopy 2020, 35, 16-26.

83. Stewart, T.J. Across the spectrum: Integrating multidimensional metal analytics for in situ metallomic imaging. Metallomics 2019, 11, 29-49. [CrossRef] [PubMed]

84. Baker, M. The 'omes puzzle. Nature 2013, 494, 416-419. [CrossRef] [PubMed]

85. Blower, P. The Elusive Roles of Metals in Human Health. Available online: www.researchfeatures.com/elusive-roles-metalshuman-health (accessed on 11 November 2021). 